\title{
The Impact Of Macroeconomic Factors In Economic Growth
}

\author{
Alush Kryeziu, PhD candidate \\ MTI Trade Department, Prishtina - Kosovo
}

doi: 10.19044/esj.2016.v12n7p331 URL:http://dx.doi.org/10.19044/esj.2016.v12n7p331

\begin{abstract}
In this paper will be discussed the main concepts and trends of the macro-fiscal indicators in economic growth, as well as their importance in the economic development of different countries, with special emphasis in Kosovo. One of the aims of this paper is to define and explain the connection between macroeconomic indicators with specific emphasis: the public debt, budget deficit and inflation on economic growth. In order to analyze this impact of variables in economic growth, the targeted time period of research is the period from 2004 to 2014. While the data taken regarding Kosovo were obtained from the year 2005, due to the fact that earlier the data have been limited because of the developments in which Kosovo went through. The model that best represents the link between macro-fiscal indicators on economic growth is the linear regression as an econometric model. We will have the opportunity to see and interpret these data. The overall results have emerged in accordance with theoretical discussions presented, but this relationship has not turned out to be very strong because the coefficients acquired did not have great explanatory skills for economic phenomena.
\end{abstract}

Keywords: Kosovo, fiscal policy, public debt, budget deficit, inflation, tax system, economic development, and the state budget targets

\section{Introduction}

Economic growth is a concept that refers to quantitative changes in economic variables and is attributed to increased overall production or per capita. This shows that we are dealing with a static process that brings quantitative changes.

Economic growth is the increase of the capacity of a country's economy to produce goods and services to a certain period of time, compared to the previous period. The economic growth can be measured in nominal terms, in which is inflation included, or in real terms, which the inflation is not included (Investopedia US, 2013). 
Regarding the concept economic growth have dealt many famous world economists trying to find and explain the role and what are the instruments that influence the economic growth of a country. Despite great interest of researchers in the field that has to do with economic growth as an indicator of macro fiscal policy, in the economic theory and practice there are not yet final determinants which show the reasons why some countries develop faster and some slower.

The concept of economic growth is more complex given that different factors may contribute to the process of economic growth. Lately, we have an increased engagement in terms of theoretical and applied researches about economic growth; in this regard we should mention some theoreticians that contributed in this field.

According to Artelarisit (2007) we still do not have a generalized theory, where economic performance is not very well conceived and understood, hence this is because of the lack of a generalized and unified theory.

Regardless these there are some partial theories that analyze the role of different factors that influence economic growth.

\section{Theoretical Concepts on Economic Growth during History}

The first economist who developed the theory of economic growth is Adam Smith. He thought that economic growth is not only conditioned by the capital accumulation, human capital, technology, land, labor, export, but from the total of all these factors in immediate manner. ${ }^{10}$

The greatest contribution of Adam Smith's economic theory is undoubtedly the introduction of the term incremental revenue in the economy based on the division of labor and specialization. Another important contribution of Smith is that he also recognized the importance of international exchange of labor and free trade as a mechanism of economic growth (Smith, "The Wealth of the nation", 1776).

The theory of economic growth was emphasized by Harrod in 1939 and Domar in 1946, who developed a model of growth saying that: "the rate of economic growth is a function of the relation between the rate of saving and the coefficient of capital (the relation of capital and output).

According to this model, the coefficient of capital is equal to ICOR* (ICOR = relation between the rate of investment / rate of investment in GDP and the growth rate of the real GDP) i.e., the reciprocal value of the marginal return of capital. ${ }^{11}$

\footnotetext{
${ }^{10}$ Adam Smith "The Wealth of the nation", 1776.

${ }^{11}$ Harrod \& Domar Report Citing the work of 1939 \& 1946.
} 
The theory of economic growth in the late 50's was created by neoclassical main representative Robert $M$. Solow (Nobel laureate for economics, where the model is called neoclassical model of Solow's growth.

Solow was focused on three elements: technology, capital and labor. Soloe came to the conclusion that "less than half of the productivity growth in the US, per capita productivity and real rentability payments can be attributed to the increase of its capital". ${ }^{12}$

By the mid 80's except the neoclassical growth theory almost no important research was established in connection with the theory of economic growth. But this year we have the development of theories and empirical analysis of economic growth, amended by so far the first ones known as "endogenous growth theories." These theories are associated with the names of P.M. Remer, R.E. Llukas, E. and G. Grossman Heplman. These economists begun with their theories on the assumption that a single decision maker will be more rational and not adaptor.

\section{Impact of Fiscal Indicators (Determinants) on the Economic Growth}

Economic growth is a complex macroeconomic phenomenon. It is difficult to fully explain which of fiscal determinants are the most important that influence on economic growth. Seen from the effect that fiscal indicators have on economic growth shows that each of these have a profound impact on economic growth and it is difficult to distinguish between that which of these indicators has greater weight in economic relations. The following three fiscal indicators will be discussed and examined and which have a dominant influence on economic growth, and these are: the public debt, budget deficit and inflation.

\section{Public Debt and its Impact on Economic Growth Overview on the Theories of Public Debt}

Public debt is one of the instruments that takes part and influences in the creation of public general revenues for at least the short term period. Public debt depends primarily on the state relation with the international financial lending organizations, although earlier has been based on the interstate relations because they have received loans from the states.

Moreover, the orientation of public debt could be used to finance the budget deficit, but also to finance investment projects that are with strategic character or other purposes. Taking public debt can have positive and negative effects, in cases where public debt is used for economic development, these tools are very beneficial, and on the contrary if these funds are not used for economic development, in this case public debt will

\footnotetext{
${ }^{12}$ Robert M. Solow, “Growth Theory” 1950.
} 
become a burden to future generations in order to repay this debt. If public debt is used for important financing that gives immediate and apparent effect to the economic growth, will influence in the reduction of unemployment and help the public revenue. In contrast, if they do not realize this economic growth, the level and its cost will be much higher, as well as the effect of limiting the social policies.

Theoretical literature that deals with the public debt is very early and it is divided into different economic schools of which the most important are: - $\quad$ Classic Views - see public debt as a burden to society. Classic economists used to refer to the public debt as a major problem for society.

- $\quad$ Ricardian Views - see public debt as a future tax (Barro 1974). The financing of the budget deficit through taxation would have the net effect on national income in the long term period (Mankin, 2002).

- $\quad$ Neoclassical Views - the public debt of the head as detrimental to investments and economic growth.

- $\quad$ Modern Economic Views - explain public debt as a boost to economic growth if the funds are used for productive purposes and as a necessary tool of a modern economy, especially for developing countries.

Relevance of public debt and economic growth has been accepted in numerous tests of European economists. In this regard, significant contribution has been given by Pattille (2002) who found out that high levels of public debt lead to a negative effect on economic growth, due to the burden that it becomes for the countries.

However, many economists have discovered a positive role of public debt on economic growth. Abbass and Christensen (2007) attempted to study the role of domestic public debt on economic growth.

\section{Types of Public Debts}

We distinguish few types of public debts:

a) According to the source of territorial origin we distinguish these types: Internal Debt; and External Debt

b) In terms of the deadline of public debt repayment we have: Short term public debt (1-5 years); Midterm public debt (1-10 years); Long term public debt (10-50 years)

c) By the method of debt repayments we distinguish two types: the debt in the form of permanent rents and the debt in the form of government bonds.

\section{Public Debt in Kosovo}

The public debt in Kosovo has different specifics due to the fact that one part of the public debt was inherited from the time of the former Yugoslav Federation. At that time Kosovo received the means in the form of 
public debt by the World Bank in the amount of $€ 220.6$ million. The service for processing external debt began in 2009 where under the existing agreement, the debt must be returned to the World Bank until 2031 twice a year.

Another external debt of Kosovo was conducted by the Standby Agreement, which was achieved in 2012 through which funds are received by the international financial institutions, namely by the IMF, in the amount of $€ 22.1$ million which must be returned by 2015 .

Besides external debt in economic development policy of public finances in the Republic of Kosovo we have the domestic debt, which for the first time in January 2012 issues securities, which are held three auctions and as a result we have emission of treasury bonds in the amount of $€ 10$ million with a maturity of 91 days.

In the table below, we will present Kosovo’s public debt from 2009 to 2014.

\begin{tabular}{|c|c|c|c|c|c|c|}
\hline \multicolumn{7}{|c|}{ Table 1. Public debt in Kosova 2009-2014 } \\
\hline & 2009 & 2010 & 2011 & 2012 & 2013 & 2014 \\
\hline External Debt & 249,01 & 260,42 & 253,60 & 336,60 & 323,76 & 326,35 \\
\hline Central Level & 249,01 & 260,42 & 253,60 & 336,46 & 321,73 & 316,54 \\
\hline Sub-loans & 0.00 & 0,00 & 0,00 & 0,14 & 2,03 & 9,81 \\
\hline State grants & 0.00 & 0,00 & 0,00 & 0,00 & 0,00 & 0,10 \\
\hline Internal Debts & 0.00 & 0,00 & 0,00 & 73,51 & 152,51 & 256,52 \\
\hline Central Level & 0.00 & 0,00 & 0,00 & 29,78 & 152,51 & 256,52 \\
\hline Municipalities & 0,00 & 0.00 & 0,00 & 0,00 & 0,00 & 0,00 \\
\hline $\begin{array}{c}\text { Total G.P. According to } \\
\text { the Law of public debt }\end{array}$ & 249,01 & 260,42 & 253,60 & 409,92 & 476,27 & 582,87 \\
\hline $\begin{array}{c}\text { Total Public Debt as \% } \\
\text { of GDP }\end{array}$ & $6,37 \%$ & $6,22 \%$ & $5,51 \%$ & $8,44 \%$ & $9,10 \%$ & $10,63 \%$ \\
\hline
\end{tabular}

Source: Ministry of Finance of the Republic of Kosovo, annual report 2014.

From the table we conclude that Kosovo until 2009 did not take public debt and that debt this year has been $€ 249.01$ or expressed in \% GDP was $6.37 \%$. Kosovo had the lowest debt in 2011 which expressed in \% of GDP was 5.51\%, while the highest was recorded in 2014 which expressed as a \% of GDP amounts to $10.63 \%$.

Based on the available data we conclude that Kosovo's public debt is low and that there are opportunities to grow even more in order to create tools for greater development of the economy. Expressed in percentage Kosovo's public debt was over $11 \%$ and it is the lowest in the region.

\section{The Budget Deficit and the Impact to Economic Growth}

The budget deficit as a phenomenon in the economy has emerged after the First World War. Nowadays most of the world economies are faced by the budget deficit being presented as the problem which affected 
countries are faced by this economic phenomenon. The budget deficit is bad for the economy of a country and it strikes the developed countries as well as developing countries.

The budget deficit has an impact on all macroeconomic variables such as inflation, economic growth, unemployment that are considered key indicators of economic development in a country.

The causes of deficit are different, but can be divided into two groups depending on the level of development of the countries where we have:

- $\quad$ budget deficit in industrialized countries, and

- $\quad$ budget deficit in emerging economies.

In financial accounting, the budget deficit emerges when the state revenues are smaller than its expenditures, therefore, the budget balance is negative. Also, the public administration (the entirety of other central organizations, local government and social security administration) recognize a public deficit when the public expenditure of one year is higher than public revenues; then the balance of public finances is negative. In case the budget inflows are greater than outflows we are talking about a budget surplus, this is a case that happens rarely. Specifically, in most of the countries public budgets (as measured by an annual periodicity) are built into deficit.

In order to balance the accounts, the deficit can be compensated by: - borrowing, this relocates the problem in time, necessary the confidence of creditors and has a supplementary cost since the interest needs to be paid;

- $\quad$ use of previously accumulated reserves from the budget surpluses realized in previous years;

- $\quad$ raising taxes, assuming that they do not stifle the economic activity, which will lead to the reduction of revenues to the public budget.

Conversely, the reduction of taxes designed to stimulate economic growth will increase many times the fiscal revenue;

- $\quad$ Monetary emission;

- $\quad$ Reduction of public expenditure.

- $\quad$ The debts of private entities and its citizens.

When debts taken are used productively for economic development, then they can be beneficial. Otherwise they become a heavy burden for the future generations of the country, which will have to face their repayment.

Public debt is divided into internal debt (taken by economic agents resident in the country) and external debt (taken by other countries or international organizations and financial institutions). From the standpoint of repayment period, public debt can be short, medium and long-termed. 
Public debt is often measured as a percentage of GDP. This indicator is economically more convenient than the value of public debt itself. In fact, the capacity of a state to reimburse its debt is a function of the resources that it can mobilize for this purpose. Resources are a function of the size of GDP, because the tax measure is in direct proportion to the country's economic activity. So, the weight of public debt is a function of GDP the richer the country is, the more you can borrow. There is a classification of countries by public debt (according to the OECD), expressed as a percentage of GDP.

The budget deficit is expressed also in Kosovo who for the first time was presented in 2010 because the government expenditures for $€ 81,060,000$ were higher than the budget revenues. ${ }^{13}$

To get a clearer picture regarding the budget deficit in Kosovo, through the 2014 Budget Balance will presented in the table below:

\begin{tabular}{|c|c|c|c|c|c|c|c|}
\hline \multicolumn{8}{|c|}{ Table no. 2. Budget deficit of Kosovo 2008 - 2014} \\
\hline Description & 2008 & 2009 & 2010 & 2011 & 2012 & 2013 & 2014 \\
\hline Revenues & 959,88 & 1.142 .39 & $1.138,97$ & $1.311,26$ & $1.383,41$ & $1.355,72$ & $1.349,48$ \\
\hline Expend & 957,64 & $1.138,01$ & $1.220,03$ & $1.362,89$ & $1.444,96$ & $1.490,24$ & $1.512,12$ \\
\hline $\begin{array}{l}\text { Budget } \\
\text { balance }\end{array}$ & 2,24 & 4,38 & $-81,06$ & $-51,43$ & $-61,55$ & $-134,52$ & $-162,67$ \\
\hline
\end{tabular}

Source: KSA for different years Prishtina, December, 2014.

Comment to table no 2. If we refer to the data in the table published by KSA we can conclude that by 2010 Kosovo had no budget deficit. In 2008 and 2009 we had the opposite, a budget surplus, and since 2010 we have deficit where the government expenditure is higher than the revenues collected. In 2014 Kosovo had the highest deficit where the difference between the Revenues and Expenditures was €162,670,000.

\section{The Impact of Inflation in Economic Increase}

Given that the inflation reflects the change in the price level, as the direct indicators are used the price indicators. Such a calculation is not easy, given the fact that the prices of various goods rise at different levels and even some of them are reduced.

For the calculation of inflation mainly economists use economic growth as a percentage of the price. The importance of studying the phenomenon of inflation is due to the fact that it affects the whole population which in modern economy is done to alleviate the impact of inflationary situations.

Inflationary disorders are the result of wrong economic policies. Inflation is classified into three categories:

\footnotetext{
${ }^{13}$ Website of Ministry of Finance, Kosovo, January 2012.
} 
- $\quad$ Moderated inflation occurs when the overall price level rises slowly and its rate is expressed in single-digit rate. In the conditions of the modern inflation the prices are relatively stable and the monetary systems are well-functioning.

- $\quad$ Fulminant inflation is accompanied by the rising prices by two and three-digit rate (20\%, 100\%, annually). In these situations the functioning of the economic system suffers serious disorders.

- Hyperinflation is a rare phenomenon in world economies and is present especially in conditions of war. Prices rise many times during a month; such examples are the rise in prices in the years 1922-33, where the index rose from 1 to 10 million, Bolevin example in 1985 with 12,000\%.

\section{Sources and types of inflation}

There are different views on the causes and sources of inflation. The view that inflation tends to be "inertia" (namely with unchanged rate), while in economy there did not occur significant changes in the side of demand and supply, thus based on the analyses of resources of inflation, we distinguish the following:

- Inertial Inflation, otherwise called predictable inflation or expected for the time that the inflation rate is stable and when changes occur on the side of supply and demand in most industrialized countries, inflation process is characterized by inertia.

- Inflation from demand occurs when there is an increase in aggregate demand as a result of an increase in the money supply, or a direct increase in expenditure for goods and services.

- Inflation of the supply happens when we have an increase of aggregate supply due to a reduction in money demand, or reduction of direct expenditures for goods and services.

While inflation of the cost is a new phenomenon in the modern market economies, it occurs when there is an increase in production costs and as a result of the increase of the cost of imported materials due to the internal factors (growth rate and depreciation of currency) or the external market, the increase in indirect taxes, etc. The uniqueness of the inflation from the cost is the rise of prices in terms of recession, so when the economy is declining.

\section{Costs of inflation}

In a period of inflation, not all prices (including wages) differ with the same extent and pace and thus as a result we will have changes in relative prices. It is these changes in relative prices that create two effects of inflation and that is: 1 . The inflation which creates a distribution of wealth between 
different classes or layers of population; and, 2. The inflation which sends into inefficient blockage of production resources.

\section{Inflation in Kosovo}

Inflation in Kosovo is imported due to the fact that the trade exchanges are negative and that is somewhere around 90\%. Kosovo imports most of the products from the international market and any increase of prices in the world would hit the country. The best indicator of price-level changes in a country is inflation. So far, inflation in Kosovo has been sustainable and has not exceeded $10 \%$. Below we will present the data graphically of annual inflation rates from 2004 to 2014.

Graph Nr.1. Annual inflation

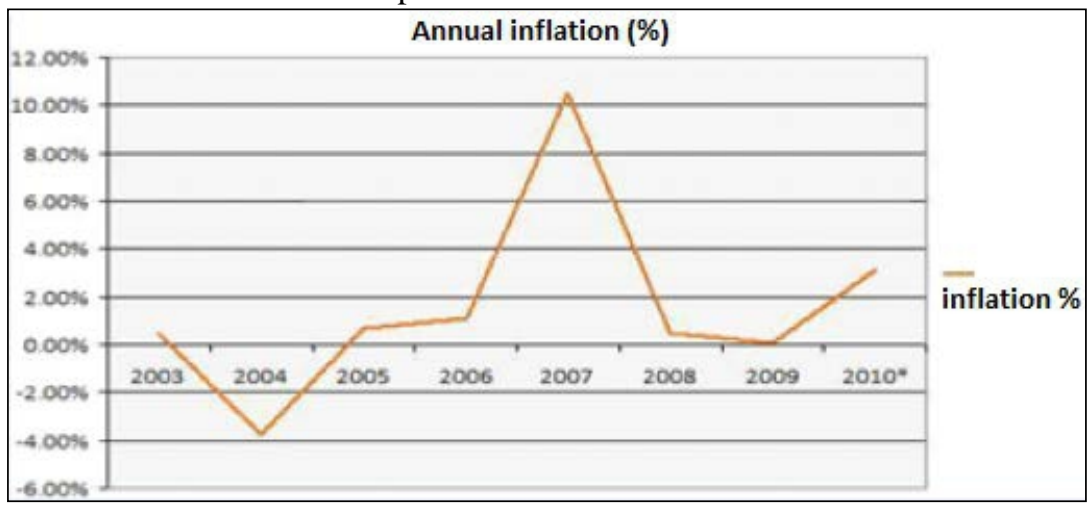

Source: Kosovo Statistical Agency

From the data presented in graph nr.1, we understand that inflation in Kosovo had oscillation, where in 2004 we have also deflation, while the highest level was reached in 2007, in that year inflation expressed in numerical values was nearly $10 \%$.

According to the experts of economic issues the data published in Kosovo prevails a lower demand for goods being at the same level with other countries in the region and that the inflation will remain at low levels.

Inflation in Kosovo mostly affects the poor, with low monthly incomes or those living on social assistance, says Rukiqi. He recommends the Government to support the development of private sector and increase the domestic production. I think that regarding the inflation as a recommendation should be that "The government should make efforts to contribute to boosting domestic production and not to depend on imports. It should work on long-term orientations that these cyclical crises that are brought by inflation to respond through the increase of supply in the country." 14

\footnotetext{
${ }^{14}$ www.albeu.com/kosove
} 
Econometric Model of Economic Growth and Fiscal Indicators (public debt, budget deficit and inflation)

save "Ci | Users | INFO PC Desktopl a. otta"

fil e C: Users | | NFO PC Desktopl a. ota saved

. regress y $\times 1 \times 2 \times 3$

\begin{tabular}{|c|c|c|c|c|c|}
\hline Source & SS & $d f$ & NS & \multirow{4}{*}{\multicolumn{2}{|c|}{ 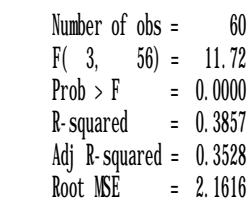 }} \\
\hline Model & 164,31701 & \multirow{2}{*}{\multicolumn{2}{|c|}{$\begin{array}{rr}3 & 54.7723365 \\
56 & 4.6727194\end{array}$}} & & \\
\hline & 261.672286 & & & & \\
\hline Total & 425. 989296 & \multicolumn{2}{|c|}{597.22015755} & & \\
\hline y & Coef. & Std. Err. & t & $P>t \mid$ & [95\% Conf. Interval] \\
\hline$x 1$ & $\therefore 015345$ & 0009661 & $\cdot 1,56$ & 0.126 & . 0351091 \\
\hline$\times 2$ & 3417207 & . 078602 & 4.35 & 0.000 & 1842621 \\
\hline$\times 3$ & . 1106505 & 00771641 & 1.43 & 0.157 & . 0439277 \\
\hline cons & 2.581564 & .7344348 & 3.52 & 0.001 & 1. 110315 \\
\hline
\end{tabular}

Paper author, Prishtina 2015.

One of the main policies that influences the economic growth but also the economic development are fiscal policies. Therefore, there are taken some elements of fiscal policy and divided into three variables and through them their effect on economic growth will be analyzed.

To see the effect of these variables on economic growth, we have used multivariate linear regression model because the data are presented in time series. This model is capable of explaining this economic phenomenon, because it makes the link between these variables seeing the connection between one and the other.

The data were taken from the International Monetary Fund for 109 countries presented for the period 2004 to 2014. The countries involved have a distribution in almost all continents which affects the analysis of fiscal policy indicators to be representative in economic growth. Also, in the processing of data are included the countries based on the organizations that function, for example the case of the EU, but also the overall average of all countries of the world.

These data will be processed by linear regression and we will see what is the effect of these variables and then it will be analyzed the odds that this model gives, but nevertheless it is expected that the effect of the independent variables will be negative or positive and not zero because in case of a zero it means that there is no connection between them and therefore, would show that errors were made in the selection of variables in the model because they have no impact on the dependent variable in this case in economic growth. 
The variables are presented in several forms, some are presented in percentages some as growth and based on them will appear the model "log lin" and "log - log", which means that the dependent variable is the variable expressed in percentage, while the independent variables are numeric values expressed in percentage.

While if it is presented on the basis of mathematical formula it takes this form:

Where: Y - economic growth;

$$
\mathbf{Y}=\alpha+\beta \mathbf{x} 1+\beta \times 2+\beta \times 3
$$

$\alpha$ - constant;

$\beta$ - coefficient;

$\mathrm{X} 1$ - the budget deficit;

$\mathrm{X} 2$ - the public debt; and

$\mathrm{X} 3$ - inflation.

According to the data processed regression formula took this form:

$\mathrm{Y}=2.58-0.015 X 1+0.34 X 2+0.11 X 3$

\section{Processing and Interpretation of Data}

Data are processed through multivariate linear regression, through which are issued the coefficients that show the influence of determinants in economic development and also other coefficients that show consistency and accuracy of these parameters.

It is important to emphasize first that in the presented model the independent variables have an impact on the presentation of variables depending only $38.5 \%$, i.e., on the basis of its coefficient of determination it appears to be 0.385 , while the coefficient of remedy appears to be $12: 35$, less than the coefficient of determination.

Therefore, regardless of the variables in the analysis, they are or are not significant and then the economic growth is explained by other variables that are not included in the model.

Below it will be presented in a general way the model by which the results are taken from the data processing software STATA.

Economic growth $=2: 58-0: 340.015+$ budget deficit public debt inflation + 00:11

\section{'t' Statistics: 3:52 to 1:56 4:35 1:43}

In most cases the economic analysis through constant linear regression does not represent any economic sense, so this is the flaw of linear regression. But this paper shows that there is a link between the constant and economic model which is presented, because obviously if all other variables are constant then economic growth will be from $2.58 \%$, an increase that was the average of the averages of various states presented in the model. 
Next we will present the results obtained separately for the variables in the model and also will analyze the results obtained and at the end we will present the general interpretation of the results of linear regression.

\section{The Impact of the Budget Deficit on Economic Growth}

As mentioned in the beginning the budget deficit is estimated to have a negative effect on economic growth because with its increase the government has smaller impact on economic long term development. Therefore, based on the evaluation of the determinants, it is shown that the connection has proven to be negative for the case of increasing the budget deficit to one percent, then we will have discounts for 0.015 percent economic growth, as shown below.

\section{Economic growth $=2: 58-0015$ budget deficit}

\section{'t' Statistics: 3:52 to 1:56}

So the effect of the budget deficit for 109 countries taken in the model as well as the European Union and the data taken worldwide for the period 2004-2014 has negative effects. But, based on 't' statistics shows that this variable is not significant in explaining economic growth because it is lower than 1.96 in absolute value, or if seen through the value ' $p$ ' does not meet the requirement of 1,5 and 10 percent. Negative effect mainly appears when there are structural budget deficit because the state puts into more debt and consequently larger debt increase pressures on fiscal policy.

\section{The Effect of Public Debt on Economic Growth}

Public debt as an instrument of governments serves to implement their development policies, and plays an important role in overall economic development. Based on the data which are processed through the data about the effect of public debt on growth, it appeared that public debt had a positive impact on economic growth in countries that are under review.

\section{Economic growth + 0:34 $=2: 58$ public debt}

\section{'t' Statistics: 3:52 4:35}

Upon growth of public debt for one unit, it has emerged that the effect on growth is 0.34 percent, so there is a positive correlation between them. Thus, whether the coefficient of 0.34 is consistent, proved that there is a stable relationship. If it is seen with the ' $t$ ' statistics, then it gets much higher in value than the minimum it should have of 1.96 in order to be considered as stable. Also, considering that the standard error is seen as minor it has no significance to the leading coefficient and the 'p' value shows that the main coefficient is stable. 


\section{The Effect of Inflation on Economic Growth}

Inflation as one of the major diseases of various countries economy is estimated to have negative effects on the overall stability of the country. But it is proved that a low and controlled inflation in most cases has a positive impact on the economy because it serves as an incentive for further development of economic activity.

But considering the list of countries included in this model, it shows that there are countries that have different economic development and it is expected the effect to be negative.

\section{Economic growth $=2: 58+0.11$ Inflation}

\section{'t' Statistics: 3.521 .43}

Based on the derived results, it can be seen that inflation has a positive effect on economic growth because the growth of one percent inflation will be 0.11 percent of economic growth. But, although this is a positive coefficient, it is not important since other coefficients are not sufficiently large to support and make sustainable the positive link between inflation and economic growth.

But, it is important to emphasize that the data in terms of inflation are generally low because of the financial crisis that emerged in 2008, it has affected the reduction of economic activity and thus the economy is accompanied by falling prices due to decreasing purchasing power, so most of the countries in the model have had negative inflation.

While if analyzed in general, the data issued by multivariate linear regression shows that coefficients that emerged in line with the main economic theories that support the budget deficit negatively affects economic growth while the public debt and moderate inflation influence positively on economic growth.

Economic growth $=2.58-0.015$ budget deficit +0.34 public debt inflation $+\mathbf{0 . 1 1}$

't' Statistics: 3.52 - 1.564 .351 .43

Although this shows that these independent variables relate to the economic growth based on the statistics, we still can see that the budget deficit and inflation are not significant, since the ' $t$ ' statistics has a smaller value than 1.96 .

\section{Conclusion}

Fiscal policy is expected to provide not only economic growth for the country but also their use is claimed to provide the economic development of the country in the long run, because in the accomplishment of this policy, 
shareholders are all the citizens of the state through their taxes and they seek for their efficiency.

Based on the economic theory, it is stated that the effect of the budget deficit plays a negative role in economic growth, in the case of the analysis conducted this has come out to have a negative effect, so it is in line with economic theory. Public debt appears to be an efficient instrument which allows to the government policies have an economic growth. This is supported by the results of the analysis between public debt and economic growth which represent positive connection between them.

Although it is estimated that the inflation may have different effects on economic activity, depending on its size, in the analysis presented it is noted that there are positive effects but the effect is of no consistency which would prove positive connection. Limitation of this model in general is that the variables presented in the model do not provide great explanation for dependent variables or economic growth. Also the correlation that may exist between these variables is very close to each other.

For example, the budget deficit and public debt are directly related to each other because if there is a budget deficit it usually increases public debt to cover that deficit. In general, it can be seen that the instruments of fiscal policy have a positive impact on economic growth, but this impact is not so great. Therefore, countries that receive fiscal policies to have economic growth should take into account the characteristics of the country because they are not direct guarantors that will achieve economic growth.

\section{References:}

Perkins, D.H., Radelet, S., Lindauer, D.L. (2006). "Economics of Development” Sixth Edition, New York, London.

Schclarek, A. (2004). "Debt and Economic Growth in Developing and Industrial Countries.

Mankiw, G. (1998). “Government Debt”.

Bundo, Sh., Cana, G. (2003) "Financa”, Tiranë.

Mançellari, A., Hadri, S., Kule, Dh., Qiriçi, S. (1999) “Hyrje në ekonomi”, Tiranë.

Komoni, S. (1986) "Financat”, Prishtinë.

Limani, M. (1994) "Politika Enomike”, Prishtine.

Jelaçiç, B., (1995) “Shkenca mbi financat dhe e drejta financiare”, Prishtinë.

Agjencioni i Statitistikave te Kosovës (ASK), Prishtinë, Shtator 2013.

Rosin, H.S. (2011). “Financat publike”, Prishtinë.

Instituti RIINVEST, “Disa qeshtje kyçe te ndërtimit dhe zbatimit te poetikes Fiskale ne Kosove” Prishtinë 2001.

Instituti RIINVEST, “Ecuria e ndërtimit te politikës së tatimeve dhe taksave në Kosovë” Prishtinë, 2003 
Instituti RIINVEST, "Sistemi buxhetor i Kosovës, politikat dhe qëndrueshmëria” Prishtine, 2003.

Ministria e Financave, Raporti i thesarit , Prishtinë, 2012.

Ministria e Financave, Raporti i thesarit, Prishtine, 2008-2012

Agjencioni i Statitistikave te Kosovës, Prishtine, Shtator, 2013

John Maynard -Keynes, "Teoria e pergjithshem e punësimit, interest dhe parasë”.

Buxheti i vitit 2013,2014, Ministria e Financave, Mars 2013.

Puna dhe punësimi, Departamenti i punës dhe punësimit, 2013 dhe 2014 Raporti vjetor.

Strategjia për zhvillimin e sektorit privat 2013-2017, Ministria e Tregtisë dhe Industrisë, Prishtinë 2013. 